re hauled to the shaft by means of wire ropes driven $y$ stationary engines. In an old or badly laid-out ine, the coal may be hauled by a succession of such ngines, each haulage requiring its complement of ttendants. Conveyors could be much more widely sed to transport the coal to well laid-out loading tations, so eliminating the wasteful use of labour n subsidiary haulage systems.

In the United States and on the Continent, locoaotives are widely used underground. But the use f locomotives requires roads which are level, or early so, and the present lay-out of most British aines is such as to prohibit their widespread installaion. Roads have been driven in the coal seams, ind in general the gradients are unsuited to the use if locomotives. Continental seams are more inclined, und the practice there is to drive level roads through he solid strata, these serving as the main arteries if the mine along which the locomotives operate. Reorganization for locomotive haulage will require he preparation of great lengths of graded roadways, and if the full advantages of locomotive haulage are ;o be realized, mine cars of a high capacity will be equired. The capacities of the tubs used in British nines range from 3 to $28 \mathrm{cwt}$. - the average is probibly 12 cwt. For use with locomotives, mine cars will be required each capable of holding several tons of coal.

No details of mining practice are passed over in this unique survey. Standards of mine lighting, the Committee considers, could be materially improved with advantage to production, safety and health. Illumination at the coal face is now provided by portable self-contained lamps, but it is recommended that power-fed lighting should be installed at the coal face. Recent research has shown that the 'cold' cathode discharge lamp may well prove a safe and efficient means of illuminating underground workings.

In an interesting paragraph the appearance of colliery premises is discussed. It is true that in the past little or no attention has been paid to this point, and the "disorder and dilapidation" so often associated with colliery premises must have its psychological effects on the workmen and adversely influence public opinion on the state of the industry. An architect should be consulted when plans are being prepared for a new mine or for remodelling an old mine.

It is apparent that reform on the lines suggested in the Reid Report will require major changes in the organization of the coal-mining industry in Britain, and this is discussed under "Conditions of Success". There will need to be amalgamation of many of the smaller undertakings to form productive units of a much greater capacity, and many existing mines will become redundant. There is a note of warning to the workmen and their leaders: that if existing wage-levels are to be maintained, then there must be a considerable increase in output per manshift, and that a rebuilt industry may have to dispense with substantial numbers of unskilled workers.

In the past, the layman may have formed the view that Britain's coal problem was that of utilizing her abundant resources of coal. This report puts first things first-the fundamental problem is that of min. ing the coal efficiently, and any plans for the utilization of coal depend primarily on the availability of large quantities of cheap coal. Finally, those with no special knowledge will read the report without difficulty, assisted by a most useful glossary of mining terms.

\section{SCIENCE AND ART AT THE ROYAL ACADEMY, 1945}

\author{
By DR. A. T. HOPWOOD \\ British Museum (Natural History)
}

$I^{1}$

$T$ is a commonplace of eriticism that a painting is not only the result of the artist's competence and temperament, but also of his country and period. Thus a Titian could arise nowhere else than in Italy; neither could a Vermeer be found elsewhere than in the Low Countries. The former reflects the warm colouring of the south, and the patronage of opulent, semi-pagan princes and prelates, whereas the latter echoes the cooler skies of the north, and the solid worth of prosperous burgherdom. Some years ago, Frank Rutter, following an earlier suggestion by Sir Michael Sadler, pointed out that, from the commencement of the present century, art in the hands of its more advanced exponents became more and more violent until, in the last years before 1914, men like Kandinsky and Wyndham Lewis were painting pictures of which the themes were connected in some way or another with war.

This prophetic aspect of the psychology of art can best be realized after study of pictures extending over some years, and it may be that the six war-time exhibitions of the Royal Academy do not constitute a long enough series; but one point in particular has attracted my attention, and to add emphasis I propose to illustrate it by reference to pictures painted by academicians, or associates, that is, to the work of men who, traditionally, are not included among the most advanced members of the craft.

Consider, first of all, Algernon Newton, who in 1942 exhibited bright and sunny scenes of London's canals. As the years have passed, his sunshine has gradually become less bright and more gloomy until in the present exhibition, even in pictures of the countryside (Nos. 348, 352, 363), it has achieved that blackish quality which gleams out fitfully before the storm, and in the town has become so dramatic as almost to be theatrical (No. 68). Sir Alfred Munnings is another whose sunshine is sometimes gloomy (No. 140) and whose skies are often sad (Nos. 136, 140). On the other hand, Edward Wads. worth has two longshore scenes (Nos. 711, 715) of a type sufficiently advanced to satisfy any but the most perfervid worshipper of 'isms'. His colours are strong and the first impression is one of stimulus akin to that of a cocktail, but the stimulus soon passes and a vague feoling of malaise, as it were a sense of the malevolence of the inanimate, remains. These might be thought a curious sequence and combination to occur as a long and hard-fought war drew slowly to a victorious close, but they are not unintelligible when considered in relation to the gradual realization of the thorny problems which would beset the peace. makers.

A painter's problems are exemplified by the work of James Fitton. "Woman Reading" (No. 61) and "Country Interior" (No. 602) belong to a group of works which he has shown during the last few years, and which are chiefiy exercises in the management of red, perhaps the most difficult of all colours except purple, of which more later. These two canvases show, as they were bound to do, how the primary colour, red, tends towards its secondaries (orange and purple) and the secondaries towards the tertiaries: or, if this theory of colour be considered too old- 
fashioned, they may be regarded as essays in the harmony of orange and rod, and the employment of suitable contrasts and discords. So far as one may judge from the background of "Reclining Figure" (No. 678), the artist himself would prefer the latter theory.

Purple in its lighter tones has ruined many acres of canvas in pictures of the 'sheep-among-the-heather' type, but in its deeper tones it is rich and magnificent, though still dangerous. The State portraits by Gerald Kelly (Gallery III) are noteworthy for the skill with which the imperial purple is rendered, a skill which cannot be fully appreciated without the realization that instead of the usual foils of green and brown these great masses of colour are displayed in a setting of parian coolness, and yet never for one stroke of the brush does the colour get out of control. True, the gold embroideries are a help in achieving this end, but they are by no means the whole of the story.

On an adjacent wall in the same gallery, "Dr. Clive Forster-Cooper, F.R.S., Director of the Natural History Museum", by Meredith Frampton (No. 165), blends complete mastery of the painter's materials with consummate draughtsmanship. For the former, reference may be made to the contrast in texture between the surfaces of the dog's jaw in the left lower corner and of the series of plaster models of some upper molars of primitive mammals scattered over the table in seeming disarray, while the drawing is summed up by the open book in which is epitomized a whole course of perspective and line. Another excellent portrait hangs in the far corner of the same room. It is L. Campbell Taylor's portrait of "The Rt. Hon. the Lord Macmillan, G.C.V.O., LL.D." (No. 205), whose voluminous black robes, set against deep green curtains, are relieved by an edging of silver lace. A more intimate type of portraiture is "Professor A. G. Tansley, F.R.S.", by W. G. de Glehn (No. 302), in which the sitter is shown, pipe in hand, in the quiet of a book-lined study.

Of the war pictures, "Torpedoing of the Tirpits by Midget Submarines" by Richard Eurich (No. 569) gave me most pleasure. No minefields, even in the clear waters of the Norwegian fiords, were ever so visible as these-never was there such a whelk as crawls on the bottom of this sea, yet all have their place in this picture, and no one would wish them away. Whether or not we have here an echo of the Futurist 'plastic interpenetration of matter' I neither know nor care; drawing, design and painting are all good, and the picture pleases me.

As usual, the sculpture is a very mixed lot. To the zoologist the more or less naturalistic works such as "Tarka", by P. E. Norman (No. 1248), "Leopard" by Hermon Cawthra (No. 1281), and "Rhesus Monkey" by Josephine Hunt are the most attractive, and he will probably find that most of the horses are better than usual. On the other side of the account he will put "Long-nosed Hedgehog" (No. 1293), if only on account of the unpleasant colour of the marble, as well as the lumpy "Messenger" (No. 1359) and the brutish "Infant Dionysus". One cannot complain of the stone in which the two last are worked; it successfully conceals the sculptures.

The architectural exhibits are fewer than last year. In the main they are pleasantly uninspired, but two of them call for particular comment. "Durham City Replanned", by Thomas Sharp (No. 1201), is ambiguous. If the new buildings in the foreground are really meant to be of the boot-box style, then the incongruity between them and the castle and cathedral in the background is so violent as almosi to be bad manners and not merely bad art; if, or the other hand, they are mere symbols to indicat where new building will be necessary, one must defer judgment until the designs for the actual buildings have been produced. The other doubtful case is Sir Giles Gilbert Scott's design for the new Coventry Cathedral, of which the interior does not strike one as suitable for an ecclesiastical building, neither does it appear to be in keeping with the exterior.

Taking the exhibition as a whole, it is lively, varied, and of good quality. To expect it to indicate a definite trend in any particular direction, or in favour of any one school, is unreasonable, since to do so would be to upset the general balance of the whole; but any visitor with some knowledge of the development of European art during the past fifty years will say of the Royal Academy, as was said of another body on an earlier occasion, " $\mathrm{E}$ pur si muove".

\section{OBITUARY}

\section{Sir Napier Shaw, F.R.S.}

Srr NaPier Shaw, whose death occurred on March 23, was born on March 4, 1854, in Birmingham, the son of Charles Thomas Shaw, manufacturing goldsmith and jeweller. He was the sixth child in a family of eight, four brothers and four sisters. $\mathrm{He}$ married in 1885 Sarah Harland, lecturer in mathem. atics at Newnham College and daughter of Dr. Thomas Harland of Salford.

Shaw received his school education at King Edward's School in his native city, and throughout his long life retained a lively interest in his old school, serving on its governing body for many years. In 1872 he won a scholarship to Emmanuel College, Cambridge, and went into residence with the avowed intention, as he often told his friends, of entering the Indian Civil Service. He read mathematics, coaching under Routh, and was 16th Wrangler in the Tripos of 1876. Later in the same year he obtained a first class in the Natural Sciences Tripos, with distinction in physics. In the following year the College elected him to a fellowship and that seems to have been the end of the suggestion to embark on an administrative career in India. Cambridge was to be his home for the next twenty-two years apart from a short time spent in Berlin, working under Helmholtz.

Shaw soon made his mark in colloge and university. Lord Rayleigh appointed him demonstrator at the Cavendish Laboratory, jointly with R. T. Glazebrook, and to that combination we owe the "Practical Physics" which became a standard text-book in schools and colleges up and down the country wher. ever experimental work formed part of the physics course. He gave up the demonstratorship in 1887 to become University lecturer in experimental physics and in 1898 was appointed an assistant director of the Cavendish. His early scientific work was along lines that have little connexion with what was to become his life work. His first published paper (Proc. Cambridge Phil. Soc., 1879) dealt with experiments with mercury electrodes, and was followed a few years later by one in the Philosophical Magazine on the atomic weights of silver and copper. Miscellaneous papers on various subjects followed. Ventilation was 